\title{
Stock Market Reaction to ECFA Announcement in Taiwan Chemicals Listed Stock
}

\author{
Ming-Chin Chin, Jing-Jye Tzeng \\ Aletheia University, Taipei, Taiwan \\ Wei-Ting $\mathrm{Yu}$ \\ Ta Hwa Institute of Technology, Hsinchu, Taiwan
}

\begin{abstract}
Taiwan and Mainland China signed the Economic Cooperation Framework Agreement (ECFA) on 29th June, 2010. The ECFA is a landmark bilateral trade agreement that can make Taiwan a new gateway to Mainland China. However, the Taiwanese petrochemical industry would be very disappointed with the early harvest list as it excluded some critical export items. The purpose of this paper is to amend the understanding of the possible impact on petrochemical market after ECFA is enacted. The authors examine the cumulative daily response of stock prices to five announcements about the ECFA and evaluate the existence of the abnormal return. The authors use daily data from January 2010 to February 2011 to employ an event study approach. The empirical results suggest that the three ECFA announcement dates, as well as the signing date, show significantly negative abnormal return due to the prior positive cumulative response of Taiwan chemicals listed stock prices. This paper can provide the petrochemical industry manufacturer, owners, and investors with further insights into how chemicals stock returns react to a big event like ECFA.
\end{abstract}

Keywords: ECFA, event study method, abnormal return, announcement effect

\section{Introduction}

As regional economic integration is becoming the global trend, on 29th June, 2010, Taiwan and Mainland China signed the Economic Cooperation Framework Agreement (ECFA). The ECFA is a landmark bilateral trade agreement that will make Taiwan a new gateway to Mainland China. It could provide a framework for Taiwan and China to gradually reduce tariffs on goods, remove non-tariff trade barriers, open up service sectors, and ease investment restrictions, eventually leading to not only economic, but also overall cooperation of cross-strait relations (see Table 1). In the meanwhile, the ECFA might also open possibilities for Taiwan signing free trade agreements (FTA) with other regional economies and economic blocs.

Based on the early harvest listing, Mainland China will cut tariffs on 539 items valued $\$ 13.8$ billion to Taiwan (about 16 percent of the total exports of Taiwan to the mainland), and correspondently, Taiwan will cut tariffs on 267 items from Mainland China worth \$2.86 billion (about 10.5 percent of the shipments of Mainland China to Taiwan).

Ming-Chin Chin, Ph.D., Assistant Professor, Department of Economics, Aletheia University.

Jing-Jye Tzeng, Master, Graduate program in Finance, Aletheia University.

Wei-Ting Yu, Ph.D., Assistant Professor, Department of Finance, Ta Hwa Institute of Technology.

Correspondence concerning this article should be addressed to Ming-Chin Chin, No.32, Zhenli St., Danshui Dist., New Taipei City 25103, Taiwan. E-mail: au4239@au.edu.tw. 
Table 1

The Comparison of ECFA, CEPA, and FTA

\begin{tabular}{|c|c|c|c|}
\hline Project & ECFA & CEPA & FTA \\
\hline Signature object & Taiwan and Mainland China & Mainland China and Hong Kong & Between the two countries or regional \\
\hline Reciprocity & Cross-strait relations. & $\begin{array}{l}\text { The Hong Kong special } \\
\text { administrative region of China. }\end{array}$ & Parallel to the principle of reciprocity. \\
\hline Objective & $\begin{array}{l}\text { Promote cross-strait cooperation, } \\
\text { for more favorable conditions of } \\
\text { Taiwan's } \\
\text { development. }\end{array}$ & $\begin{array}{|lll|}\text { China and } & & \\
\text { Hong Kong to strengthen } \\
\text { economic cooperation and } \\
\text { integration. }\end{array}$ & $\begin{array}{l}\text { To promote economic cooperation and } \\
\text { elimination of tariff barriers. }\end{array}$ \\
\hline Coverage & $\begin{array}{l}\text { Merchandise trade, services, and } \\
\text { investment liberalization. }\end{array}$ & \begin{tabular}{|l|} 
Trade in goods and services. \\
Trade and investment facilitation.
\end{tabular} & Trade in goods and services. \\
\hline
\end{tabular}

Note. Source: Public website.

However, the Taiwanese petrochemical industry would be very disappointed with the early harvest list as it excluded some critical export items, such as PVC. China is the biggest market for PVC in Asia, and Taiwan is one of the major PVC producing nations in Asia, other than Korea and Japan. It is roughly two-thirds of the annual chemical output of Taiwan to Mainland China.

In fact, the ASEAN-China FTA has been launched since January 1, 2010. The tariff within the zone for the most part reduced to zero, including petrochemicals. Unfortunately, at the moment, Taiwan cannot participate effectively into this economic cooperation process of East Asia as well as the world. Therefore, Taiwan is unavoidably facing the huge pressure of marginalization in globalization and regionalization.

In addition, the output value of Taiwan petrochemical industry including textile is about 20 percent of the whole manufacturing sector in the last 10 years. The population of people engaging in the petrochemical industry is about 42 million people, accounting for 18 percent of the working population in the manufacturing sector (see Table 2). Furthermore, the most output about 64 percent of Taiwan's petrochemical products export to Mainland China, so Mainland China has become Taiwan's largest export market for the petrochemical industry.

Table 2

Numbers of Employee of Taiwan's Petrochemical Industry (Units: Employee)

\begin{tabular}{llll}
\hline Year & Manufacturing & Petrochemical industry & Petrochemical industry/Manufacturing \\
\hline 2001 & $2,348,449$ & 515,680 & $22 \%$ \\
2002 & $2,318,803$ & 495,760 & $21 \%$ \\
2003 & $2,372,733$ & 486,673 & $21 \%$ \\
2004 & $2,461,369$ & 485,051 & $20 \%$ \\
2005 & $2,479,476$ & 465,619 & $19 \%$ \\
2006 & $2,510,435$ & 452,393 & $18 \%$ \\
2007 & $2,543,763$ & 446,558 & $18 \%$ \\
2008 & $2,564,542$ & 440,499 & $17 \%$ \\
2009 & $2,411,013$ & 423,909 & $18 \%$ \\
\hline
\end{tabular}

Note. Source: Directorate-General of Budget, Accounting and Statistics, Executive Yuan, China.

According to the report, if after 2010, Taiwan cannot be zero-tariff place which will lose competitive, and at the same time, China's market will lose nearly New Taiwan Dollar (NTD) one trillion, half of total value in lost export value from the petrochemical industry. In addition, the working population of 42 petrochemical companies will have no sense of stability of employment, so government and industry hope that ECFA can be signed. 
Comparing with previous studies, this paper contributes in several ways. Firstly, to the effectiveness on the cross-strait affairs, this research is one of the first researches focusing on evaluating the impact of ECFA. Secondly, the ECFA is merely the ticket to enter into the petrochemical market of Mainland China. This research, therefore, provides the information about the possible development of the future.

The purpose of this paper is to amend the understanding of the possible impact on petrochemical market after ECFA is enacted. This paper is organized as follows: At first, the definition and the timeline of ECFA are introduced, and then followed by literature review and methodology. Section three is empirical analysis. The authors employ data on Taiwan chemicals listed stocks to examine whether the abnormal return exists. The results of this paper are reported in section four. Section five presents our conclusions and comments.

\section{A General Description of the Early Harvest List on the ECFA}

The signing of the ECFA represents the trend of trade liberalization, even existence of conflicts on politics, and it also built up a common market for the two to compete.

In the first round negotiation, Taiwan apparently had more reduce-taxed items comparing to Mainland China, but it seems to be only short-term advantage. For example, the basic petrochemical raw materials already have low tariffs (propylene 1\% and xylene 2\%) before the ECFA. In addition, the electronic and mechanical parts are intermediate products. They are already tax rebated after exporting. Practically, Taiwan should fight for dismissing the China's 5\% above import tax rate. Disappointedly, there are some important items that are not included in the list, such as PVC, machine tools, as well as auto parts.

Nevertheless, the cement product though is on the list, the low export value to China is meaningless to Taiwan. However, some industries of Taiwan indeed gain the benefits in the early harvest list. For example, the firms of textile raw materials and special textiles can strengthen the compatibility, because Taiwan has strong ability of integration and R\&D capability. In addition, the leading industries in the world: the bicycles, sports equipment, medical equipment, and mechanical parts, can boost the market share further.

Furthermore, the financial industry does not rely on customs, and it has been very profitable. It shares from the two sides of capital and strategic alliances. We see a cross-strait common financial market. Under the early harvest list that Taiwan bank set point in the mainland and have profit over a year, we can apply for renminbi business, at the same time, better than the Chinese mainland to other member states of the World Trade Organization (WTO).

\section{The Current Situation of the Petrochemical Industry in Taiwan}

Petrochemical industry has played a very important role in the process of industrialization in Taiwan. Commonly known as reverse integration type of industrial development model, Taiwan's petrochemical industry is the demand from the downstream to develop and gradually invests in upstream petrochemical industry. The petrochemical industry includes upstream naphtha cracker, and the further processing of their products. Whether a boom or a recession of this industry, the main products of ethylene naphtha cracker's output are measured by indicators (Chu, 2001).

It is noted that the petrochemical industry is broadly referred to as the initial oil or natural gas as raw materials used, through various chemical reactions to synthetic, rubber, synthetic fiber, and chemical products.

Generally, the petrochemical industry can be partitioned into three sections: the upstream, midstream, and downstream. The general definitions of these are as follows: 
Upstream: Naphtha cracking, production of basic petrochemical raw materials, including ethylene, propylene, butadiene, benzene, xylene, and toluene;

Midstream: The further processing of upstream products, production of petrochemical raw materials, including plastic materials, synthetic materials, synthetic rubber raw material, etc.;

Downstream: Use of petrochemical raw materials to produce products, such as plastic products, textiles, etc..

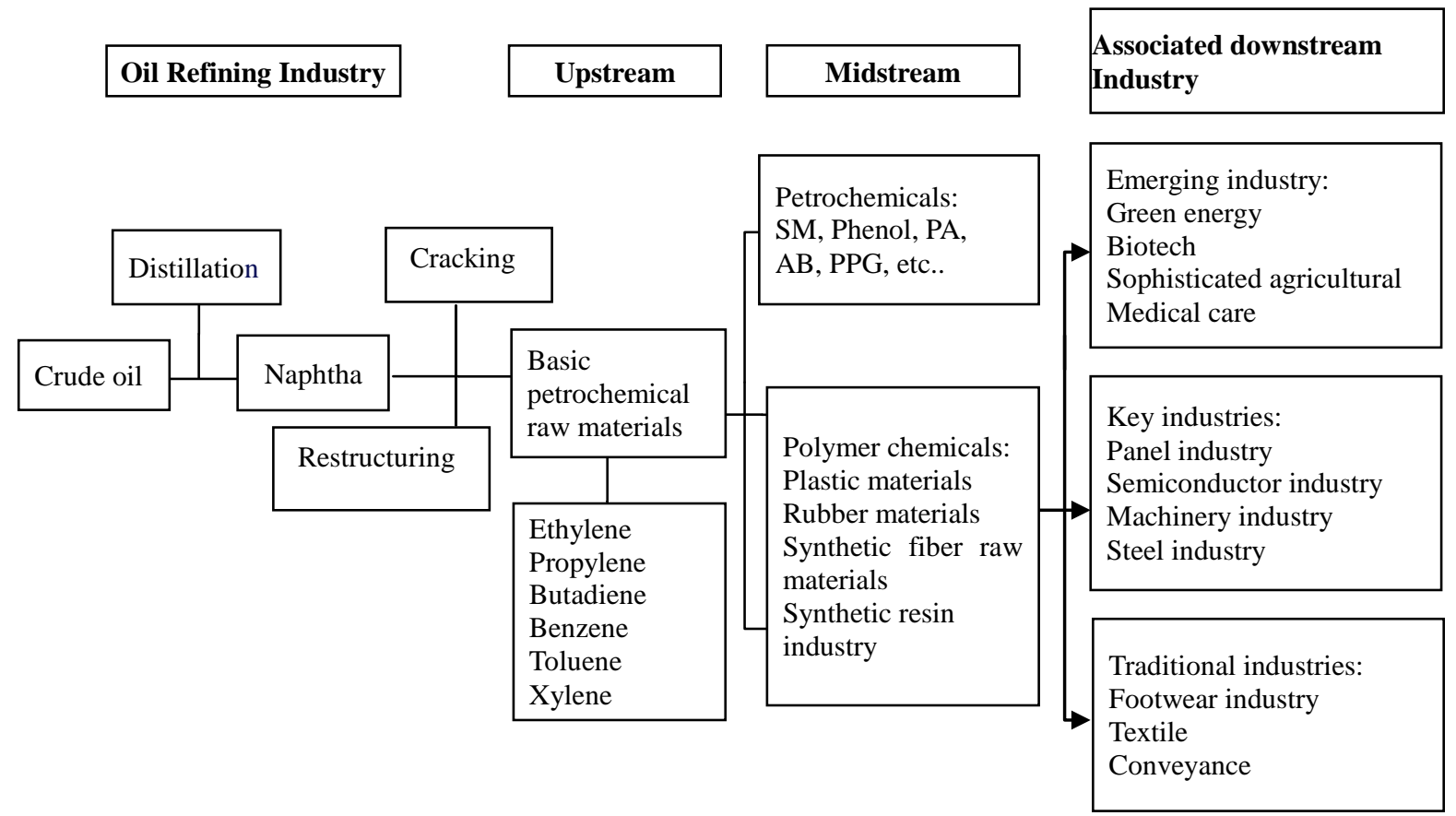

Figure 1. The scope of the petrochemical industry. Source: Industrial Development Bureau, Ministry of Economic Affairs/Taiwan Research Institute.

Table 3 summaries the Taiwan's output and export share of petrochemical products. It states that nearly 38 percent of the Taiwan's petrochemical value is from export. Table 4 is the details of the major petrochemical raw materials including PTA, SM, EG PE, and ABS. They all show that the high percentage goes to mainland China.

Table 3

Taiwan's Output and Export Share of Petrochemical Products (Units: NTD million)

\begin{tabular}{llllll}
\hline Year & Manufacturing & $\begin{array}{l}\text { Petrochemical } \\
\text { industry }\end{array}$ & $\begin{array}{l}\text { Export of petrochemical } \\
\text { products }\end{array}$ & $\begin{array}{l}\text { Petrochemical } \\
\text { industry/manufacturing }\end{array}$ & $\begin{array}{l}\text { Export of petrochemical } \\
\text { products/Petrochemical } \\
\text { Industry }\end{array}$ \\
\hline 2001 & 73,423 & 15,767 & 5,118 & $21 \%$ & $32 \%$ \\
2002 & 79,994 & 16,548 & 5,569 & $21 \%$ & $34 \%$ \\
2003 & 88,590 & 18,490 & 6,212 & $21 \%$ & $34 \%$ \\
2004 & 104,981 & 22,604 & 7,502 & $21 \%$ & $33 \%$ \\
2005 & 109,520 & 22,788 & 7,915 & $21 \%$ & $35 \%$ \\
2006 & 119,159 & 24,035 & 8,411 & $21 \%$ & $35 \%$ \\
2007 & 132,008 & 28,089 & 10,172 & $21 \%$ & $36 \%$ \\
2008 & 131,083 & 27,099 & 9,956 & $21 \%$ & $37 \%$ \\
2009 & 105,824 & 22,526 & 8,531 & $21 \%$ & $38 \%$ \\
\hline
\end{tabular}

Note. Source: Ministry of Economic Affairs, China. 
Table 4

Taiwan's Main Exports to China in 2009-The Proportion of Petrochemical Raw Materials

\begin{tabular}{lllllll}
\hline $\begin{array}{l}\text { Petrochemical } \\
\text { raw material }\end{array}$ & $\begin{array}{l}\text { Production } \\
\text { (tone) }\end{array}$ & $\begin{array}{l}\text { Foreign sales } \\
\text { (tone) }\end{array}$ & $\begin{array}{l}\text { Foreign sales } \\
\text { /Production (\%) }\end{array}$ & $\begin{array}{l}\text { China's export } \\
\text { volume (tone) }\end{array}$ & $\begin{array}{l}\text { China’s export volume China's export volume } \\
\text { /Production (\%) }\end{array}$ & $\begin{array}{l}\text { /Foreign sale (\%) } \\
\text { Propylene }\end{array}$ \\
$2,881,105$ & 547,032 & $18.99 \%$ & 484,814 & $16.83 \%$ & $88.63 \%$ \\
Butadiene & 527,016 & 110,158 & $20.90 \%$ & 62,258 & $11.81 \%$ & $56.52 \%$ \\
SM & $1,906,015$ & 531,583 & $27.89 \%$ & 467,341 & $24.52 \%$ & $87.91 \%$ \\
VCM & $1,772,586$ & 405,783 & $22.89 \%$ & 270,527 & $15.26 \%$ & $66.67 \%$ \\
EG & $2,038,649$ & $1,272,857$ & $62.44 \%$ & $1,176,478$ & $57.71 \%$ & $92.43 \%$ \\
PTA & $4,406,348$ & $2,171,769$ & $49.29 \%$ & $1,961,129$ & $44.51 \%$ & $90.30 \%$ \\
AN & 411,575 & 93,605 & $22.74 \%$ & 66,148 & $16.07 \%$ & $70.67 \%$ \\
\hline
\end{tabular}

Note. Source: 2009 Petrochemical Industry Association of Taiwan, Annual Report.

Since the China-ASEAN FTA took effect on 1st January, 2010, the tariff on a majority of exports and imports among the nations reduced to near zero. But now, the signing of the ECFA between Taiwan and Mainland China provides a new opportunity for the development of the cross-strait relations, such as the flow of people, goods, funds, information, as well as brings big business opportunity to the economic development for both two.

Following the general expectation, the ECFA would lower tariffs on goods in the textile, auto parts, machinery, petrochemical sectors, and etc. However, the disappointed outcome is that Mainland China excluded Taiwan's PVC from a list of 88 petrochemical items. At the same period of time, China's FTA with the 10 ASEAN members was already on board, allowing zero tariffs including petrochemicals on cross-border trade of a large number of products. Therefore, this result really brings severe impacts on the Taiwan petrochemical industry.

On the other hand, Tables 5 and 6 summarize that the Taiwan-made PVC and PE etc., major export items for the Chinese market, are still subject to $6.5 \%$ tariff, while those products from our main competitors such as South Korea, Japan, and Singapore already enter the market with tariff-free. As a result, the Taiwan's petrochemical industry is facing an unfair competition, and cannot win the market in Mainland China. Obviously, each released message related to the ECFA, especial for the petrochemical projects, drew everyone's attention and therefore, the stock price responded immediately, even though the message had not been confirmed.

Table 5

Petrochemical/Plastic Materials Comparison of Tariffs

\begin{tabular}{llll}
\hline & Taiwan $\rightarrow$ China (2010) & ASEAN $\rightarrow$ China (before 2010) & ASEAN $\rightarrow$ China (after 2010) \\
\hline Ethylene & 0 & 0 & 0 \\
Propylene & $1 \%$ & 0 & 0 \\
VCM & $1 \%$ & 0 & 0 \\
PVC & $6.50 \%$ & $5 \%$ & 0 \\
AA & $6.50 \%$ & 0 & 0 \\
$n$-Butanol & $5.50 \%$ & 0 & 0 \\
H/LDPE & $6.50 \%$ & $6.50 \%$ & 0 \\
LLDPE & $6.50 \%$ & $5 \%$ & 0 \\
EVA & $6.50 \%$ & 0 & 0 \\
PP & $6.50 \%$ & $5 \%$ & 0 \\
\hline
\end{tabular}


(Table 5 continued)

\begin{tabular}{llll}
\hline & Taiwan $\rightarrow$ China $(2010)$ & ASEAN $\rightarrow$ China (before 2010) & ASEAN $\rightarrow$ China (after 2010) \\
\hline CAN & $3 \%$ & $3 \%$ & 0 \\
MMA & $6.50 \%$ & 0 & 0 \\
AE & $6.50 \%$ & 0 & 0 \\
SM & $2 \%$ & $2 \%$ & 0 \\
PS/ABS & $6.50 \%$ & $6.50 \%$ & 0 \\
EG & $5.50 \%$ & $5.50 \%$ & 0 \\
PTA & $6.50 \%$ & $5 \%$ & 0 \\
\hline
\end{tabular}

Note. Source: Enterprise Research Office.

Table 6

2008 Statistics of Imports of Plastic Raw Materials in China

\begin{tabular}{lllll}
\hline Product & $\begin{array}{l}\text { The average monthly imports } \\
\text { from Taiwan (thousand tone) (\%) }\end{array}$ & $\begin{array}{l}\text { China's share of } \\
\text { total imports (\%) }\end{array}$ & Ranking & Import share of rivals (\%) \\
\hline PVC & $10-30$ & $30-40$ & 2 & Japan (40-50) \\
PP & $40-50$ & 20 & 2 & Korea (30-40) \\
PS & $20-25$ & 25 & 1 & Korea (15-20) \\
ABS & $60-80$ & 50 & 1 & Korea (30) \\
\hline
\end{tabular}

Note. Source: Enterprise Research Office.

This paper analyzes the effect of ECFA announcement. The authors examine whether or not ECFA had a significant influence on stock prices of Taiwan chemicals stock. Specifically, the authors pick three important dates, including signing date and announcement, to examine the existence of abnormal return on the related listed stocks.

\section{The Method of Event Study and Efficient Market Hypothesis}

This paper is to examine whether or not there was the abnormal return for the petrochemical industry due to the ECFA event, before and after announcement. The authors applied the event study methodology. The event study methodology that has become popular in the accounting and finance research. Some examples include mergers and acquisitions, earnings announcements. Event study methodology measures the magnitude of the effect that an unanticipated event has on the expected profitability and risk of a portfolio of firms associated with that event.

Event studies have a long history. The first published study is Dolley in 1933. In this work, he examines the price effects of stock splits, studying nominal price change at the time of the split. Later, Fama, Fisher, Jensen, and Roll (1969) proposed that the theory underlying event study methodology was the efficient market hypothesis.

Several key studies about the announcement effect of major information on stock prices, such as Castanias (1979) and Schwert (1981). Castanias suggests that the variance of stock prices rises around the days of most economic news events, which he interprets as a reflection of new information appearing. Other than simply using dummy variables for the days the announcements by Castanias and Schwert (1981) and Pearce and Roley (1983) took expected and unexpected announcements as differentiated.

\section{Past Studies}

Event of major disaster, the literature that Tsai (2003) examined is about the reaction of a catastrophe on 
the stock market. The case is the 921 Chi-Chi earthquakes in Taiwan. The results indicate that the abnormal return occurred in the stock market because of the earthquake and it was consistent with the efficient market hypothesis. The magnitude of the abnormal return was dependent on industry classification and the financial ratio of a company.

In the event of non-major disaster, Grace, Rose, and Karafiath (1995) of the United States in 1988 by proposition 103 on the insurance industry shareholder wealth effects, research showed that the insurance industry in California was not outside the 103 bills passed by the impact, and supported the efficient market hypothesis and the impact events ahead as the reaction. In addition, Woolridge and Snow (1990) studied that the declaration of major investment decisions and positive relationship between abnormal returns.

Ling (2000) used the market model to estimate the expected rate of return, and calculate abnormal returns and cumulative abnormal returns and further explore the significant investment of listed companies on the stock price announcement effects. The results showed that there was a positive effect two days after the announcement. Therefore, it supported that Taiwan stock markets are consistent with semi-strong efficient market hypothesis.

At the same time, Tian (2010) examined the daily response of stock prices to 10 announcements about the MoU from April 2009 to January 2010. There are seven MoU event dates to show significant abnormal return, in addition, the signing and effective dates of MoU have no significantly positive abnormal return due to the prior positive cumulative response of Taiwan financial listed stock prices.

Jiang (2010) studied the stocks abnormal returns after the executed announcement of the new Statement of Financial Accounting Standards (SFAS) No.10. The new SFAS No.10 is expected to make a great impact on inventories and to cause the gross margin rate to descend and the influences get confirmed by the results.

\section{Methodology}

The component attributed to firm-specific events like the ECFA event is called abnormal return. The abnormal return (AR) is the actual expected return of the security over the event window minus the normal return of the firm over the event window. If an announcement of an event is good news, we expect AR to be positive, indicating that the market believes that the event will increase the firm's value. On the contrary, a negative AR signals bad news and the market believes that the event would decrease the firm's future profitability.

Accordingly, the authors calculate the mean abnormal return and the cumulative mean abnormal return (CAR) on an event date for sampled firms experiencing the same firm-specific event to capture the valuation impact of that event. The authors then test the statistical significance of the CAR. If the cumulative abnormal return is statistically different from zero, we can say that the event significantly influences stock prices.

\section{Market Model}

To measure the ARs of chemical stocks, we need to estimate the expected returns (ER) of chemical stocks. In this paper, we employ the market model which relates the return of any given security to the return of the market portfolio (Fama et. al., 1969). For any security $i$ the market model is:

$$
R_{i t}=\alpha_{i}+\beta_{i} R_{m t}+\varepsilon_{i t}
$$

where $R_{i t}$ and $R_{m t}$ are the period $t$ returns on security $i$ and the market portfolio, respectively and $\varepsilon_{i t}$ is the zero mean disturbance term. The parameters of the market model can be estimated by OLS regression-i.e., $\hat{\alpha}_{i}$ and 
$\hat{\beta}_{i}$. The return can be written as:

$$
\hat{R}_{i E}=\hat{\alpha}_{i}+\hat{\beta}_{i} R_{m E}
$$

\section{Event Window and Estimation Window}

To facilitate the measurement and analysis of abnormal returns, returns will be indexed in event time using $t$. The signing date is on June 29, 2010 and the effective date is on January 1, 2011. Defining $t=0$ as the event date, $t=t_{2}$ to $t=t_{1}$ represents the event window. Based on previous study, let the length of the estimation be 300 days (Brown \& Warner, 1980, 1985; Dyckman, Philbrick, \& Stephan, 1984). Figure 2 is the time line of this study.

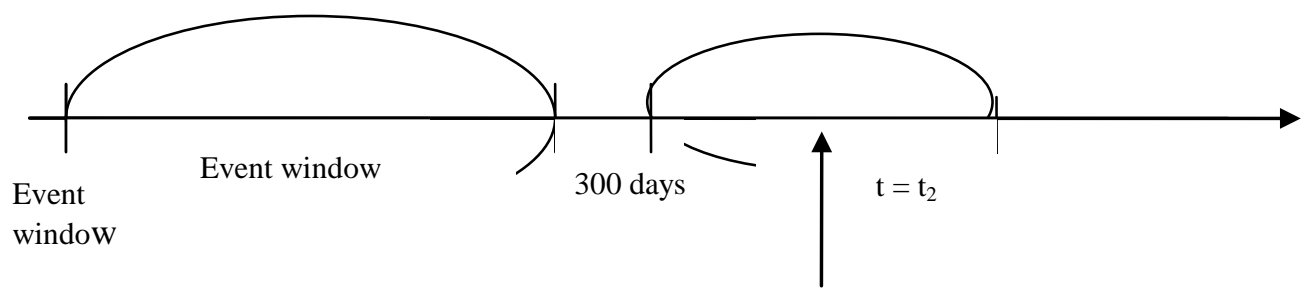

Figure 2. Time line for this event study.

\section{Statistical Test of Abnormal Returns}

Using the market model to measure the normal return, the sample abnormal return is:

$$
A R_{i E}=R_{i E}-\left(\hat{\alpha}_{i}+\hat{\beta}_{i} R_{m E}\right)
$$

Let $A R_{i E}$ be the sample of abnormal returns from firm $i$ in the event window. Thus, average Abnormal Return, $\left(\mathrm{AR}_{\mathrm{E}}\right)$ can be as:

$$
A R_{E}=\frac{1}{N} \sum_{i=1}^{N} A R_{i E}
$$

The $C A R_{E}$ from $t_{1}$ to $t_{2}$ is the sum of the included abnormal returns-Cumulative Abnormal Return(CAR)

$$
C A R_{\tau 1, \tau 2}=\sum_{E=\tau 1}^{\tau 2} A R_{E}
$$

Based on Patell (1979), most studies are use modification to standardize each abnormal return using an estimator of its standard deviation. This paper employs Zibart's $(1985,1990)$ modification:

$$
\begin{gathered}
S A R_{E}=\frac{1}{N} \sum_{i=1}^{N}\left(\frac{A R_{i E}}{\sqrt{\operatorname{VAR}\left(A R_{i E}\right)}}\right) \\
S C A R_{E}=\sum_{i=\tau 1}^{\tau 2} S A R_{E}
\end{gathered}
$$

\section{Modifying the Three Research Questions and the Hypothesis Test}

(1) Whether signing date or announcement date of ECFA has impact on the behavior of the returns?

(2) Whether different ECFA events have impact on the behavior of the returns?

(3) Whether announcement date of ECFA has impact on the Taiwan petrochemical listed stocks?

\section{Data and Empirical Results}

The data for stock prices period used in this paper begins on January 1, 2010 and ends on February 25, 
2011, including 286 trading dates. The ECFA event date corresponding to the availability of the data used to represent expectations and information is around the time of the government or official announcements. All datasets are obtained from the Infotimes and the Taiwan Economic Journal (TEJ).

We employ the measure suggested by Beaver (1982) and Fama $(1970,1976,1991)$ and define the continuously compounded return as follow:

$$
R_{i t}=\ln \left[\frac{P_{i t}}{P_{i t-1}}\right]=\ln \left(P_{i t}\right)-\ln \left(P_{i t-1}\right)
$$

Let $R_{i t}$ be continuously compounded return from firm $i$ in event-day $t$ and $P_{i t}$ be the stock price from firm $i$ in event-day t. All samples are the daily stock return in Taiwan chemicals listed stocks (see Table 7).

Table 7

ECFA Event Announcements Related to the Taiwan Chemical Listed Stocks

\begin{tabular}{|l|l|}
\hline Event and its date & Event announcement \\
\hline No. 1, May 25, 2010 & 90 percents of petrochemical products in Taiwan were not listed in the early harvest list. \\
\hline No.2, June 30, 2010 & ECFA has been signed on 29th June, 2010. \\
\hline No. 3, August 18, 2010 & $\begin{array}{l}\text { Chiang and Chen will meet for the sixth-run negotiation in next March, and the petrochemical } \\
\text { industry will be included in the discussion. }\end{array}$ \\
\hline No. 4, December 3, 2010 & Chiang and Chen meeting for the sixth-run negotiation postponed until the end of December. \\
\hline No. 5, December 22, 2010 & Chiang and Chen meeting for the sixth-run negotiation and the era of tax cuts are coming. \\
\hline
\end{tabular}

\section{Two Specific Announcements Are the Event Date}

The impact of announcements about ECFA on the daily percentage change in stock prices is estimated. Event window $(-30,0)$ are used to test the hypothesis that ECFA has impact on the behavior of the returns. In other words, we examine whether information leakage exists. Respectively, event window $(0,30)$ is used to test the detention effect.

In Table 8, event No. 1, May 25, $2010(t=0)$ shows significant negative abnormal returns (SCAR = $-2.059 \%)$. This means that security prices had already responded to the "expected" part of the market spread of petrochemical products which are not included in the ECFA early harvest list. Besides, the market spread of petrochemical products is not included in the ECFA early harvest list announcement. Without this ECFA issue there would be "disappointed" investors in the stock market. Event No. 3, August 18, $2010(t=0)$ shows significantly positive abnormal return (SCAR $=4.0217 \%$ ), and it is 14 days before $(t=-14)$ gradually increasing rate of return and the return rate of four at the beginning of the first. In addition, return to the maximum on day $4(t=+4)$ and within one month after the announcement are all positive abnormal returns. Indicating that investors were optimistic about the petrochemical into the ECFA discussed is the future of related industries will benefit.

Event No. 4, the meeting being postponed can be regarded as a bad news. Table 8 shows that AR is $-0.2122 \%(5.2099 \%-4.9977 \%)$ and is significant. In addition, event No. 4 is a case of market overreaction, because the share price has a significant rebound in the $t=+1$ and the AR is from negative to positive $0.4322 \%$ $(-4.7777 \%+5.2099 \%)$.

Event No. 5, the sixth-run C-C meeting confirms the launch date for the harvest list on 1st January, 2011. However, it did not include the related issues on the petrochemical industry, and then stock returns reach the biggest value at $t=0($ SCAR $=-3.5473)$. After the event date, the stock return did not have severe fluctuation. 
Table 8

\begin{tabular}{|c|c|c|c|c|c|}
\hline $\begin{array}{l}\text { Event } \\
\text { window }\end{array}$ & $\begin{array}{l}\text { Event No. 1 } \\
\text { SCAR }\end{array}$ & $\begin{array}{l}\text { Event No. } 2 \\
\text { SCAR }\end{array}$ & $\begin{array}{l}\text { Event No. } 3 \\
\text { SCAR }\end{array}$ & $\begin{array}{l}\text { Event No. } 4 \\
\text { SCAR }\end{array}$ & $\begin{array}{l}\text { Event No.5 } \\
\text { SCAR }\end{array}$ \\
\hline-30 & 0.1493 & 0.057 & -0.1437 & -0.5457 & $-2.7744^{* * *}$ \\
\hline-29 & 0.087 & $0.3959^{*}$ & $-0.4026^{*}$ & $-2.3407^{* *}$ & $-1.9327^{*}$ \\
\hline-28 & 0.1947 & 0.1574 & -0.4079 & -0.9404 & $-2.7043^{* * *}$ \\
\hline-27 & 0.4971 & $-0.5742^{*}$ & -0.4051 & -1.0321 & $-6.0626^{* * *}$ \\
\hline-26 & -0.106 & $-0.5787^{*}$ & -0.2709 & $-2.956^{* * *}$ & $-5.4209^{* * *}$ \\
\hline-25 & -0.2706 & $-1.233^{* * *}$ & $-0.7803^{* *}$ & $-3.747^{* * *}$ & $-5.2046^{* * *}$ \\
\hline-24 & -0.1461 & $-1.576^{* * *}$ & -0.4949 & $-4.9227^{* * *}$ & $-4.4807^{* * *}$ \\
\hline-23 & -0.1308 & $-1.202^{* * *}$ & -0.031 & $-5.1595^{* * *}$ & $-4.6362^{* * *}$ \\
\hline-22 & -0.2261 & $-1.0138^{* * * *}$ & -0.1869 & $-5.4577^{* * *}$ & $-5.6629^{* * *}$ \\
\hline-21 & -0.4293 & $-1.4493^{* * *}$ & -0.0761 & $-5.5232^{* * *}$ & $-5.163^{* * *}$ \\
\hline-20 & -0.3204 & $-1.5736^{* * *}$ & 0.3066 & $-3.8018^{* * *}$ & $-5.0278^{* * *}$ \\
\hline-19 & 0.1934 & $-1.5772^{* * *}$ & 0.6384 & -1.3382 & $-6.0788^{* * *}$ \\
\hline-18 & 0.5316 & $-1.8157^{* * *}$ & 0.5835 & -1.3761 & $-6.4982^{* * *}$ \\
\hline-17 & -0.0255 & $-1.6299^{* * *}$ & 0.7912 & $-2.0907^{* *}$ & $-5.4665^{* * *}$ \\
\hline-16 & -0.1656 & $-1.6086^{* * *}$ & $1.049^{*}$ & $-2.0419^{* *}$ & $-4.4016^{* * *}$ \\
\hline-15 & 0.0096 & $-1.5508^{* * *}$ & 0.9215 & $-2.512^{* *}$ & $-4.7206^{* * *}$ \\
\hline-14 & -0.2703 & $-1.7266^{* * *}$ & $1.2788^{* *}$ & $-4.2819^{* * *}$ & $-5.2488^{* * *}$ \\
\hline-13 & -0.5117 & $-1.4794^{* *}$ & $1.68^{* * *}$ & $-4.1503^{* * *}$ & $-5.4748^{* * *}$ \\
\hline-12 & -0.8229 & $-1.7769^{* * *}$ & $1.4286^{* *}$ & $-4.2001^{* * *}$ & $-4.8994^{* * *}$ \\
\hline-11 & -0.3966 & $-1.7623^{* * *}$ & $1.2681^{*}$ & $-3.8985^{* * *}$ & $-4.8694^{* * *}$ \\
\hline-10 & -0.4676 & $-1.9914^{* * *}$ & $1.9533^{* * *}$ & $-4.0816^{* * *}$ & $-4.6969^{* * *}$ \\
\hline-9 & -0.7049 & $-1.9577^{* * *}$ & $1.8192^{* * *}$ & $-4.8198^{* * *}$ & $-5.0138^{* * *}$ \\
\hline-8 & -0.7425 & $-1.9373^{* * *}$ & $2.7057^{* * *}$ & $-4.5889^{* * *}$ & $-5.4313^{* * *}$ \\
\hline-7 & -0.6745 & $-2.1602^{* * *}$ & $2.8767^{* * *}$ & $-4.568^{* * *}$ & $-4.9842^{* * *}$ \\
\hline-6 & -0.7703 & $-1.8997^{* *}$ & $2.8471^{* * *}$ & $-5.3579^{* * *}$ & $-4.7127^{* * *}$ \\
\hline-5 & -0.7236 & $-1.4044^{*}$ & $2.8014^{* * *}$ & $-5.7359^{* * *}$ & $-3.8533^{* * *}$ \\
\hline-4 & -0.399 & $-1.3155^{*}$ & $3.0769^{* * *}$ & $-5.0505^{* * *}$ & $-3.2549^{* * *}$ \\
\hline-3 & -0.6567 & $-1.5819^{* *}$ & $3.6233^{* * *}$ & $-4.3258^{* * *}$ & $-3.649^{* * *}$ \\
\hline-2 & $-1.3945^{*}$ & $-1.3654^{*}$ & $3.7476^{* * *}$ & $-4.5693^{* * *}$ & $-3.5985^{* * *}$ \\
\hline-1 & $-1.3975^{*}$ & $-1.482^{*}$ & $3.662^{* * *}$ & $-4.9977^{* * *}$ & $-3.5953^{* * *}$ \\
\hline 0 & $-2.059 * *$ & $-1.5293^{*}$ & $4.0217^{* * *}$ & $-5.2099^{* * *}$ & $-3.5473^{* * *}$ \\
\hline 1 & $-2.3891^{* * *}$ & -1.3474 & $3.9567^{* * *}$ & $-4.7777^{* * *}$ & $-3.0964^{* * *}$ \\
\hline 2 & $-2.0224^{* *}$ & $-1.695^{* *}$ & $3.9568^{* * *}$ & $-4.7842^{* * *}$ & $-3.1213^{* * *}$ \\
\hline 3 & $-1.8451^{* *}$ & $-1.9632^{* *}$ & $4.2786^{* * *}$ & $-4.6752^{* * *}$ & $-3.4379^{* * *}$ \\
\hline 4 & $-2.2719^{* *}$ & $-2.1148^{* *}$ & $4.3885^{* * *}$ & $-4.9568^{* * *}$ & $-3.3786^{* * *}$ \\
\hline 5 & $-2.399^{* * *}$ & $-2.2389^{* *}$ & $3.8522^{* * *}$ & $-5.3257^{* * *}$ & $-3.7137^{* * *}$ \\
\hline 6 & $-2.4114^{* * * *}$ & $-2.4617^{* * *}$ & $3.696^{* * * *}$ & $-4.9868^{* * *}$ & $-3.8748^{* * *}$ \\
\hline 7 & $-2.6414^{* * *}$ & $-2.463^{* * *}$ & $3.8507^{* * *}$ & $-4.7838^{* * *}$ & $-3.9482^{* * *}$ \\
\hline 8 & $-2.4602^{* * *}$ & $-2.4761^{* * *}$ & $3.532^{* * *}$ & $-4.0933^{* * *}$ & $-3.337^{* * *}$ \\
\hline 9 & $-2.459^{* * *}$ & $-2.3762^{* *}$ & $3.1216^{* * *}$ & $-3.6085^{* * *}$ & $-2.2899^{* *}$ \\
\hline 10 & $-2.4142^{* *}$ & $-2.8143^{* * *}$ & $3.7101^{* * *}$ & $-3.933^{* * *}$ & $-2.3113^{* *}$ \\
\hline 11 & $-2.6009^{* * *}$ & $-2.5672^{* * *}$ & $3.6764^{* * *}$ & $-3.9103^{* * *}$ & $-2.309^{* *}$ \\
\hline 12 & $-2.3677^{* *}$ & $-2.1609^{* *}$ & $3.4717^{* * *}$ & $-3.9088^{* * *}$ & $-3.0203^{* * *}$ \\
\hline 13 & $-2.6535^{* * *}$ & $-2.3178^{* *}$ & $3.6952^{* * *}$ & $-3.8749^{* * *}$ & $-3.4976^{* * *}$ \\
\hline 14 & $-2.6353^{* * *}$ & $-2.2112^{* *}$ & $3.8209^{* * *}$ & $-3.4946^{* * *}$ & $-3.8874^{* * *}$ \\
\hline
\end{tabular}


(Table 8 continued)

\begin{tabular}{|c|c|c|c|c|c|}
\hline $\begin{array}{l}\text { Event } \\
\text { window }\end{array}$ & $\begin{array}{l}\text { Event No. } 1 \\
\text { SCAR }\end{array}$ & $\begin{array}{l}\text { Event No. } 2 \\
\text { SCAR }\end{array}$ & $\begin{array}{l}\text { Event No. } 3 \\
\text { SCAR }\end{array}$ & $\begin{array}{l}\text { Event No. } 4 \\
\text { SCAR }\end{array}$ & $\begin{array}{l}\text { Event No.5 } \\
\text { SCAR }\end{array}$ \\
\hline 15 & $-2.8505^{* * *}$ & $-1.8788^{*}$ & $4.1646^{* * * *}$ & $-3.5334^{* * *}$ & $-3.7619^{* * *}$ \\
\hline 16 & $-2.8236^{* * *}$ & -1.6009 & $3.8335^{* * *}$ & $-3.8062^{* * *}$ & $-3.7984^{* * *}$ \\
\hline 17 & $-2.8115^{* * *}$ & -1.6554 & $3.4112^{* * *}$ & $-3.7626^{* * *}$ & $-3.3344^{* * *}$ \\
\hline 18 & $-3.0193^{* * *}$ & -1.4863 & $2.8777^{* * * *}$ & $-4.0536^{* * *}$ & $-2.8579^{* * *}$ \\
\hline 19 & $-2.7648^{* * *}$ & -1.2892 & $2.8398^{* * *}$ & $-4.1993^{* * *}$ & $-2.7831^{* * *}$ \\
\hline 20 & $-2.3006^{* *}$ & -1.398 & $2.9869^{* * *}$ & $-4.262^{* * *}$ & $-3.1122^{* * *}$ \\
\hline 21 & $-2.2197^{* *}$ & -1.0695 & $2.7802^{* * *}$ & $-3.7337^{* * *}$ & $-3.1714^{* * *}$ \\
\hline 22 & $-2.4915^{* *}$ & -0.7249 & $2.6869^{* *}$ & $-2.8219^{* * *}$ & $-2.9328^{* * *}$ \\
\hline 23 & $-2.2866^{* *}$ & -0.9442 & $2.9617^{* * *}$ & $-2.8623^{* * *}$ & $-2.7072^{* * *}$ \\
\hline 24 & $-2.4101^{* *}$ & -1.0911 & $2.7277^{* *}$ & $-2.8591^{* * *}$ & $-2.8253^{* * *}$ \\
\hline 25 & $-2.4678^{* *}$ & -0.4916 & $2.7463^{* *}$ & $-3.5076^{* * *}$ & $-3.3815^{* * *}$ \\
\hline 26 & $-2.3003^{* *}$ & -0.6155 & $3.0369^{* * *}$ & $-3.9373^{* * *}$ & $-3.7089^{* * *}$ \\
\hline 27 & $-2.6369^{* *}$ & 0.1548 & $2.6887^{* *}$ & $-4.2748^{* * *}$ & $-3.8719^{* * *}$ \\
\hline 28 & $-2.8968^{* *}$ & 0.3058 & $2.8056^{* *}$ & $-4.1676^{* * *}$ & $-2.9082^{* * *}$ \\
\hline 29 & $-3.0428^{* * *}$ & 0.266 & $2.4967^{* *}$ & $-4.2067^{* * *}$ & $-2.0966^{* *}$ \\
\hline 30 & $-3.1699^{* * *}$ & 0.2034 & $2.3871^{* *}$ & $-3.7979^{* * *}$ & -1.422 \\
\hline
\end{tabular}

Notes. T: two-tailed test; ${ }^{*}$ significant at $90 \%$ level; ${ }^{* *}$ significant at $95 \%$ level; and ${ }^{* * *}$ significant at $99 \%$ level.

\section{The Signing Date Is Used to Be the Event Date}

Event No. 2, June 30, 2010. The estimation results indicate that the impact is statistically significant at the event day -14 until event day +15 , and the response is negative in Table 8 . The sign ECFA that the market already know and events to determine, so investors are starting to sell the stock, pay rate began to fall off until the 10 day $(t=10)$ after the signing of returns to the lowest point (SCAR $=-2.8143 \%)$ and after at the 11 day $(t$ $=11$ ) of the beginning rate of return reversal up. Rate of return takes about 40 days down to the lowest point, but took only 17 days to return back to position a month before (see Figure 3), and indicating that investors were overreacting.

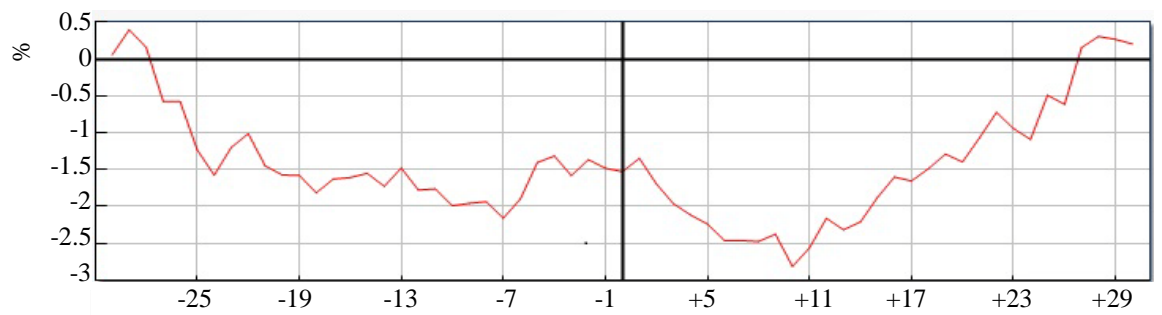

Figure 3. Plot of cumulative abnormal return for earning ECFA—signing date from event day -30 to event day 30.

Liang and Mullineaux (1994) investigated stock price behavior before and after surprise events. They constructed four basic portfolios and then extended further 16 control portfolios, examined the event direction, the magnitude of event-day surprises, and the potentially confounding effects due to calendar regularities in stock returns. The capital market data from 1964 to 1989 was used. They found a pre-event stock price behavior pattern and also confirm the existence of the overreaction pattern ${ }^{1}$.

\footnotetext{
1 The overreaction hypothesis asserts that stocks which have underperformed the market over a period of time (often one to five years) will outperform the market over a subsequent and similar time period. This was first noted by DeBondt and Thaler (1985) who found, using US data from 1926 to 1982, those previous losers outperformed previous winners by nearly 25\% over the subsequent three year period.
} 


\section{Summary and Conclusions}

Generally, the ECFA can be regarded as a watershed in cross-strait relations, meanwhile, it gives Taiwan an opportunity to connect to the East Asian economy with fairer terms. Therefore, from now on, Taiwan should take efforts to pursue preferential trade deals with other countries.

Indeed, the ECFA is very important to the economic future for both sides, Taiwan and China. It will help boost Taiwan's economy by improving exports, attracting more foreign investment and creating more jobs. In addition, the agreement may change Taiwan's economy fundamentally and China will become Taiwan's largest trading partner. However, Taiwan's exports are being threatened by Southeast Asia due to ASEAN signing their own free-trade agreements with Beijing. On the other hand, ECFA may help maintain Taiwan's competitiveness.

The results of this research provide the petrochemical industry manufacturer, owners, and investors with further insights into how chemicals stock returns react to big event like ECFA. This study examines the impact of the ECFA event on stock returns of chemicals listed in Taiwan. De bondt and Thaler (1985) stated that the stock market in violation of the weak formed an efficient market and made on overreaction hypothesis; on the other hand, they were to support that the large fluctuation in stock prices followed the stock price after the reverse change.

As for those not appearing in the early harvest list of products, such as automotive, panel, and 17 related dominated industries, they are still have a chance on the list in future trade negotiations. Based on our perspectives, the ECFA may bring obvious benefits or immediate revenues in the short term, but it definitely will help the Taiwan petrochemical industry remain it's in a highly dominant role in the long term.

Till now, six negotiations have been done, and the process keeps going. The following negotiations and key issues may include commodity trade, service trade, and investment agreements, etc.. Finally, this research concludes that Taiwan, from global strategies, shall focus on its strengths, strive for equal terms on trading, and bring the largest welfare gains for its people. Meanwhile, Taiwan shall keep playing a positive role and participating positively in regional and global affairs. By doing so, Taiwan's political stability can be insured.

\section{References}

Beaver, W. H. (1982). Discussion of market-based empirical research in accounting: A review. Journal of Accounting Research, 20, 323-331.

Brown, S. J., \& Warner, J. B. (1980). Measuring security price performance. Journal of Economics, 8, 205-258.

Brown, S. J., \& Warner, J. B. (1985). Using daily stock returns: The case of event studies. Journal of Financial Economics, 14, 3-31.

Castanias, R. P. (1979). Macroinformation and the variability of stock market prices. Journal of Finance, 34, 439-450.

Chu, W. (2001). The petrochemical industry in Taiwan's post-liberalization economy. A Radical Quarterly in Social Studies, 44, 13-47.

Douglas, K. P., \& Roley, V. V. (1985). Stock prices and economic news. Journal of Business, 58(1), 49-67.

De Bondt, W. F. M., \& Thaler, R. (1985). Does the stock market overreact?. Journal of Finance, 40(3), 793-805.

Dyckman, T., Philbrick, D., \& Stephan, J. (1984). A comparison of event study methodologies using daily stock returns: A simulation approach. Journal of Accounting Research, 22, 1-33.

Fama, E. F. (1970). Efficient capital markets: A review of theory and empirical work. Journal of Finance, 25, 383-417.

Fama, E. F. (1976). Foundation of finance. New York: Basic Books.

Fama, E. F. (1991). Efficient capital market: II. Journal of Finance, 5(46), 1576-1611.

Fama, E. F., Fisher, L., Jensen, M. C., \& Roll, R. (1969). The adjustment of stock prices to new information. International Economic Review, 10, 1-21.

Grace, E. V., Rose, L. C., \& Karafiath, I. (1995). Using stock return data to measure the wealth effects of regulation: Additional evidence from California’s proposition 103. Journal of Risk and Insurance, 62, 271-285. 
Industrial Development Bureau Ministry of Economic Affairs. (2010). Petrochemical industrial policy assessment report.

Jiang, S. P. (2010). The exploration of the stocks abnormal returns after the executed announcement of the new Statement of Financial Accounting Standards (SFAS) No. 10 (MA dissertation, National Central University).

Liang, Y., \& Mullineaux, D. J. (1994). Overreaction and reverse anticipation: Two related. Journal of Financial Research, 17, 31-43.

Ling, J. D. (2000). Significant investment of listed companies on the stock price impact of announcement (MA dissertation, Tunghai University).

Patell, J. M. (1979). The API and the design of experiments. Journal of Accounting Research, 17(2), 528-549.

Pearce, D. K., \& Roley, V. V. (1983). The reaction of stock prices to unanticipated changes in money: A note. Journal of Finance, 38, 1323-1333.

Schwert, G. W. (1981). The adjustment of stock prices to information about inflation. Journal of Finance, 36, 15-29.

Tian, C. J (2010). Stock market reaction to MOU Announcement in Taiwan financial listed stock (MA dissertation, Aletheia University).

Tsai, C. Y. (2003). Effects of the catastrophe on stock market: The case of the 921 Chi-Chi earthquakes in Taiwan's electronics, banking, and construction industries (MA dissertation, National Kaohsiung First University).

Woolridge, J. R., \& Snow, C. C. (1990). Stock market reaction to strategic investment decisions. Strategic Management Journal, 11, 353-363.

Zibart, D. A. (1985). Control of beta reliability in studies of abnormal return magnitudes: A methodological note. Journal of Accounting Research, Autumn, 920-926.

Zibart, D. A. (1990). The association between consensus of beliefs and trading activity surrounding earnings announcements. The Accounting Review, 65, 477-488. 